\title{
Abstract not included for publication
}

BMC Neuroscience1471-2202201112Suppl 1P364

Published: 18 July 2011

doi:10.1186/1471-2202-12-S1-P364

Cite this article as: : Abstract not included for publication. $B M C$

Neuroscience 2011 12(Suppl 1):P364.

Submit your next manuscript to BioMed Central and take full advantage of:

- Convenient online submission

- Thorough peer review

- No space constraints or color figure charges

- Immediate publication on acceptance

- Inclusion in PubMed, CAS, Scopus and Google Scholar

- Research which is freely available for redistribution

Submit your manuscript at www.biomedcentral.com/submit
C Biomed Central 